\title{
Local Wisdom in Shifting Cultivation Management of Dayak Ngaju Community, Central Kalimantan
}

\author{
Eti Dewi Nopembereni ${ }^{1}{ }^{*}$, Sugiyanto ${ }^{2}$, Keppi Sukesi ${ }^{2}$ and Yayuk Yuliati ${ }^{2}$ \\ ${ }^{1}$ Study Program of Agribusiness, Faculty of Agriculture, University of Palangka Raya \\ ${ }^{2}$ Study Program of Agribusiness, Faculty of Agriculture, Universitas of Brawijaya Malang
}

(Received March 10, 2019; Accepted March 27, 2019; Published May 16, 2019)

\begin{abstract}
This study aims to identify the local wisdom in the management system of shifting cultivation in Dayak Ngaju, Central Kalimantan. The study was conducted at Mantangai Tengah Village and Mantangai Hilir Village, Mantangai District, Kapuas Regency, Central Kalimantan. Purposive sampling was used as the method to determine the location and sample of the research (70 people). The primary data used were farmers or cultivators and key informants while the secondary data were obtained from BPS and related agencies. The analysis of the data was done by using a descriptive qualitative technique. The results show that the management system of shifting cultivation conducted by local people cannot be separated from the local wisdom in the community. This is indicated by some activities which explain that phenomena such as forest clearing, land burning, land management, technology utilization, and ceremony accompanying the activities of shifting cultivation. Communities live in a harmonious relationship with forests and land, manage land in a limited area (1-2 ha) without the risk of land fires, live in communal and mutual cooperation (gotong-royong), and have local knowledge that has positive value.
\end{abstract}

Keywords: Dayak Ngaju, local wisdom, shifting cultivation, Kapuas

JEL Classification: D19, 033, O35

\section{INTRODUCTION}

The people of Dayak Ngaju inhabit almost onehalf of the population in Central Kalimantan where this sub-ethnic occupies 6 districts of a total of 14 districts, namely; Palangka Raya City, Kapuas Regency, Pulang Pisau Regency, Gunung Mas Regency, Katingan Regency, and Kotawaringin Regency. This community also dominates the language (means of communication) in the entire area of Central Kalimantan. Generally, agriculture is their main livelihood (BPS Kalimantan Tengah, 2017).

As a local community, the main feature of agriculture is the shifting cultivation system which is generally done by the community (Cairns \& Garrity, 1999; Kansanga et al., 2019). For them,

\footnotetext{
* Corresponding author email: etidewin@yahoo.co.id, ISSN 2615-6075 online; ISSN 2615-6946 print @UWG Press, 2019

OJS http://publishing-widyagama.ac.id/ejournalv2/index.php/jsed/
}

shifting cultivation system is a local wisdom whose knowledge and skills are derived from the ancestors (Rodríguez, Sletto, Bilbao, Sánchez-Rose, \& Leal, 2018 ; Burns, 2015). This system does not use any technology including the type of seeds grown. In general, the community will use local seeds obtained from previously stored harvests that are not sold as they have the typical flavors, shapes, and ways to manage. The farmers do not use technology because it does not need intensive maintenance, pesticides, fertilizer, and modern mechanization tools. This is similar to previous research related to local community activities and its local wisdom (Utina, 2017; Bhagawati, Bhagawati, Das, Bhagawati, \& Ngachanngachan, 2015; Mokpokpo, 2016).

According to Provincial Regulation of Central Kalimantan Number 5 the Year 2011, local wisdom is cultural values and customs that serve as guidance in the interaction between individuals or groups with other human beings and its relationship with nature in terms of natural 
resources management and utilization. The shifting cultivation process of the local people in Central Kalimantan starts from going to the forest to search for suitable land to be cultivated as a field which is done communally (gotong royong) in all togetherness and led by a respected tribal chief whose trusted to have high knowledge about nature, type of soil, wind direction, star direction, and the right time to find the suitable land as well as to grow and maintain the farm (Amare, Wondie, Mekuria, \& Darr, 2019; Bhushan, Singh, Telidevara, \& Kumar, 2019).

The problems of shifting cultivation in Central Kalimantan are related to the issues of sustainability as well as forest and land fires both nationally and internationally. The local or traditional agricultural system is based on years of observation of the surrounding natural environment. The farmers have local knowledge for survival including cultivation. The problems in shifting cultivation are not on the matter of good or bad. Shifting cultivation is known to cause forest and land fires but the management of this system is closely related to the local communities who do the farming activities based on the local wisdom as knowledge and skills. This is in line with several previous studies stating that forest fires are not caused by shifting cultivation done by traditional society but many contributing factors (Minnemeyer et al., 2015; Nongrove et al., 2015).

Cultivation tradition, local wisdom, as well as the skills possessed by the cultivators, become the basis of this study to see the binding and important local wisdom that needs to be preserved as local knowledge and wisdom of Dayak Ngaju local community in Central Kalimantan. This is because the system of shifting cultivation is seasonal food producers and is used as the main livelihood to fulfill the needs of family food.

Local wisdom is very important in ensuring the sustainability of local farming communities, especially in the Village of Mantangai Tengah and Mantangai Hilir conjunction with shifting cultivation. Both villages have undergone a transition to settled agriculture, yet still use simple technology. The novelty of this study is the cultivation management model that is no longer shifted, but already settled and still uses a simple way of technology.
The aim of this study is to identify and describe the presence of local wisdom in the management system of shifting cultivation in Dayak Ngaju, Central Kalimantan, and its implication to government policies for controlling land and forest burning.

\section{RESEARCH METHOD}

The research was conducted in the area of Mantangai Tengah and Mantangai Hilir Village in Mantangai District, Kapuas Regency, Central Kalimantan Province. The original population in this area is $100 \%$ active cultivators with a low level of education. About $52 \%$ of them only graduated from elementary school with an average income level of nine million rupiahs per year. This area is tropical and humid climates (60\% to $90 \%$ humidity) with a temperature between $21^{\circ} \mathrm{C}$ and $23^{\circ} \mathrm{C}$. It has moderate sunlight intensity and rainfall between $1000-2600 \mathrm{~mm} /$ year. The highest rainfall occurs in October-March while the lowest usually happens between June and August.

The topography is relatively flat with an altitude between 0-28 $\mathrm{m}$ above sea level with the slope of the land ranging from $0-18 \%$. Generally, the condition of the managed soil and farmland is fineto-medium-textured alluvial soils which is a peatpotted soil containing acid sulfate. The thickness of the peat ranging from $0-50 \mathrm{~cm}$ in types of $B$ to $C$ and $\mathrm{D}$ consisting of deep peat and shallow peat. The level of acidity $(\mathrm{pH})$ of the soil ranges from 3.5 to 5.5 so that the soil tillage needs to be done carefully. In order to reduce the level of soil acidity, it is necessary to calcify the land to be managed. This study was conducted over 12 months from May 2017 to May 2018.

The purposive sampling method was used to determine the sample and location of the research. There were 70 samples consisting of 60 farmers and 10 key informants in this research. The researchers chose this location due to the existence of shifting cultivation that still found significantly so that the information about the condition of shifting cultivation done by the local community could be obtained. The research took place for 12 months from May 2017 to May 2018. The source of the data was derived from primary data and secondary data. 
The data were collected by using survey, observation, and in-depth interviews. Consequently, the data analysis was done with descriptive qualitative technique ((Ribeiro Filho, Adams, \& Murrieta, 2014) (Das \& Das, 2014); Wida, Irianto, \& Anam (2015) emphasizing on the social-economic condition of the community and farmers by (i) identifying the local wisdom of Dayak Ngaju local community in the management system of shifting cultivation, and (ii) describing the local wisdom in the management system of shifting cultivation in Central Kalimantan.

\section{RESULT AND DISCUSSION}

\section{Farming Activities}

The identification results in this study indicate that the current land preparation in the shifting cultivation system of Dayak Ngaju local community in Central Kalimantan is seen from the local wisdom that has not changed from the past. It is known that the local culture through local knowledge of the community in managing the shifting cultivation remains the same in terms of understanding and practice. Rahman, Rahman, \& Sunderland (2012) said that the main driving force of the traditional farming activity (shifting cultivation) is the culture who has been practiced from generation to generation. The traditions limit them to integrate superior varieties, species, and cultivation techniques because they are suspicious if there is a possibility of intensive agriculture (FernándezFerrín, Calvo-Turrientes, Bande, Artaraz-Miñón, \& Galán-Ladero, 2018; Berkes, Folke, \& Gadgil, 1995).

Local wisdom in this shifting cultivation system is the local values understood and recognized as guidance in farming business by the community. Moving the farming area, using customary rituals to get good land, and cleaning the land with a slash and burned technique is the traditional way in land clearing. It is considered cheap and fast with the assumption that burning can improve soil fertility and add more nutrients to it.

FAO, IWGIA, \& AIPP (2015) stated that it is important to support the role of the local community in the environmental conservation, economic activity, and social activity through a sustainable traditional agricultural activity which has been recognized gradually. It is also important to appreciate the contributions from the local community through sustainable ecosystem management and development in the form of knowledge about the natural environment and agricultural practice that is increasingly understood and appreciated.

Table 1. Local Wisdom in Shifting Cultivation Activity of the Dayak Ngaju Community

\begin{tabular}{|c|c|c|}
\hline Local terms & Description & Information \\
\hline $\begin{array}{l}\text { Setiar- } \\
\text { Sedenter-Eka } \\
\text { Satiar }\end{array}$ & \begin{tabular}{|l|} 
Leave the \\
residence \\
temporarily to \\
manage the \\
forest \\
\end{tabular} & $\begin{array}{l}\text { A local term which can be } \\
\text { interpreted as an activity in } \\
\text { shifting cultivation management }\end{array}$ \\
\hline Mahimba & $\begin{array}{l}\text { Go into the } \\
\text { forest to get } \\
\text { suitable land } \\
\text { for the } \\
\text { farming } \\
\text { activity }\end{array}$ & $\begin{array}{l}\text { This activity is done by the } \\
\text { community and led by the tribal } \\
\text { chief as guide and leader in the } \\
\text { ritual } \\
\text { The ritual includes prayer asking } \\
\text { for safety and prosperity in } \\
\text { everything they do }\end{array}$ \\
\hline $\begin{array}{l}\text { Manehar- } \\
\text { maneweng, }\end{array}$ & Forest clearing & Cutting down the big woods (tree) \\
\hline $\begin{array}{l}\text { Mandirik- } \\
\text { manatas }\end{array}$ & Land clearing & $\begin{array}{l}\text { Slashing the shrubs and grass } \\
\text { Making a track (route) for the } \\
\text { entrance and exit to the location }\end{array}$ \\
\hline Tatas & $\begin{array}{l}\text { Ditch divider } \\
\text { for the land }\end{array}$ & Making a ditch or burn barrier \\
\hline $\begin{array}{l}\text { Manusul tana- } \\
\text { sahewan }\end{array}$ & \begin{tabular}{|l|} 
Burning the \\
land with \\
particular tools
\end{tabular} & $\begin{array}{l}\text { The land burning is carried out } \\
\text { jointly where the people (in } \\
\text { charge) have been determined } \\
\text { synchronously by paying attention } \\
\text { to the instructions from the } \\
\text { leaders or officers. } \\
\text { The special burning tool is called } \\
\text { sahewan made from the dry } \\
\text { bamboo stem ( } 2-4 \text { meters). } \\
\text { Besides used as an igniter, it also } \\
\text { can be used as a torch. }\end{array}$ \\
\hline $\begin{array}{l}\text { Hajamuk- } \\
\text { wayah tugal }\end{array}$ & $\begin{array}{l}\text { Plant the rice } \\
\text { by making } \\
\text { holes in the } \\
\text { soil with wood } \\
\text { (ditugal) }\end{array}$ & $\begin{array}{l}\text { This is the biggest ceremony for } \\
\text { Dayak Ngaju people in starting the } \\
\text { rice planting. This is characterized } \\
\text { with festivity and excitement } \\
\text { aiming to draw closer the rice } \\
\text { spirit (hambaruan parel) with the } \\
\text { rice plants (parel). }\end{array}$ \\
\hline $\begin{array}{l}\text { Manggetem } \\
\text { parei. }\end{array}$ & Harvesting & $\begin{array}{l}\text { The rice plants are allowed to } \\
\text { grow until the harvest time is } \\
\text { coming. }\end{array}$ \\
\hline$-($ not difined) & $\begin{array}{l}\text { Land fallow } \\
\text { (bera) }\end{array}$ & $\begin{array}{l}\text { The land is left to rest for a while. } \\
\text { In shifting cultivation, fallow } \\
\text { means that the land cannot be } \\
\text { planted with rice again because it } \\
\text { already enters the } 3^{\text {rd }} \text { or } 4^{\text {th }} \text { times } \\
\text { of farming. According to their } \\
\text { understanding, the land is not } \\
\text { productive anymore for rice, they } \\
\text { might going to grow rubber and } \\
\text { other annual plants in the land }\end{array}$ \\
\hline- (not difined) & Rotation & $\begin{array}{l}\text { The shifting or moving of } \\
\text { cultivators to the new location. } \\
\text { Generally, they will look for } \\
\text { another land if they already have } 3 \\
\text { to } 4 \text { years of farming in the } \\
\text { previous land. }\end{array}$ \\
\hline
\end{tabular}


This shifting cultivation system is a traditional agricultural business which does not use any technology but more likely to use the system of organic farming as well as customs (traditions) and skills that are known by the community. For them, shifting cultivation is an agricultural enterprise that is laden with local wisdom in practice where this system does not exploit the forest largely or widely but adapt to the needs and abilities of the families in the farming community (Table 1 ).

Therefore, this farming culture that has the essence of local wisdom can be understood as; (1) a harmonious relationship with nature as a comprehension that forest and land is a source of life, (2) not the cause of forest and land fires because the managed land is not too extensive (12 ha) supported with firebreaks and short combustion time (3-4 hours), (3) the activities that are carried out communally and jointly (gotong royong), and (4) a local knowledge that has good values. This is in line with Kurniawan, Hartoyo, \& Syaukat (2011) that the shifting cultivation process is always performed through regular stages. In general, it is preceded by traditional ceremonies or customary rituals containing the values of nature conservation and local wisdom in terms of ecological conservation, food security, and socio-cultural condition of the local community.

Lumangkun \& Wardenaar (2017) asserted that the local wisdom in shifting cultivation activity is portrayed in several rituals, including year closing (Nyabang/Basawak), spells reading (Neriu), dancing (manarik), chicken cutting (Mentaman), eggs breaking (Tareng Temiyang), cleaning up the carcass of Bontongk, rice planting (Nurungk), land clearing (Ngudungk), and rice harvesting (Ngatok).

\section{Cropping System}

Cultivation becomes a culture of managing forest and land. This is considered important by local people as a way of life which means that there is no other way to manage the forest and land than farming. Such livelihood, relationships with nature, and maintenance of living and environment will be obtained because of this cultivation culture. Singh, Purohit, \& Bhaduri (2016) found that a shifting cultivation system conducted by local people is the unification between sociocultural, local knowledge of the traditional agricultural system, and biophysical characteristics from the locality.

The local values contained in the shifting cultivation system that is important for the community are: the land is planted with various types of food crops by a means of mix-cropping (rice, tubers, vegetables and horticulture, herbs, spices, fruits, rubber) to meet the food needs of the family. This is called by Patel, Karmakar, Sanjog, Surendra, \& Chowdhury (2013) as "the system of cultivation canteen" where almost all types of cereals, vegetables, and trees are planted in one field together.

The cropping pattern in the shifting cultivation system is usually illustrated in the planting calendar for a year of production. This is also known as the cultural wisdom of the community in determining the type, timing, and pattern of land management (Table 2)

Table 2. Local Wisdom in Annual Cropping Pattern System of The Dayak Ngaju Community

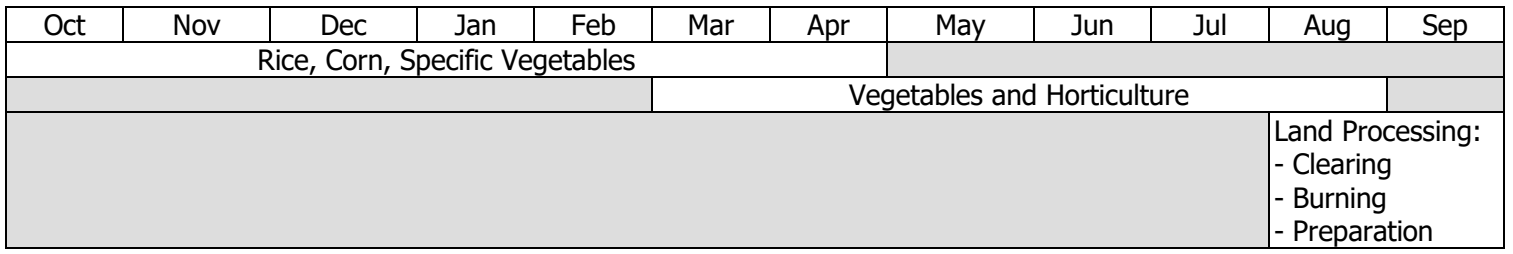

The changes in cropping patterns are shifting. Intensive cropping patterns are permanently done throughout the year. Back then, cultivation management was done with a shifting system, but now it is started to change towards settled agriculture. Temudo, Figueira, \& Abrantes (2015) argued that the shifting cultivation system transitioning to settled agriculture in Guinea-Bissau Africa did not affect the shortage of land, shortfallow, and soil fertility. On the other hand, van 
Vliet, Adams, Vieira, \& Mertz (2013) believed that the increased population, the access to markets, and the desire to control land have caused the shifting cultivation system turning into a classical intensification system in the Brazilian Amazon region.

The changes from shifting cultivation system to settled agriculture are portrayed in Table 2 (planting calendar). Rice crops are governed from October to April. Between March and August, the land is managed for vegetables and horticulture. Starting from August to September, the land is cleared again for the rice fields. Generally, the farmland is managed by various crops in a single field. This is a tradition from the local community in utilizing their fields including some specific types of vegetables (eggplant, katuk, taro, aubergine). Those are some types of plants that are allowed to grow along with the growth of rice and corn as food crops by the community.

The results of this study are in accordance with the previous research that shifting cultivation system in multiple regions around the world experiencing a transition to become unsustainable and either settling or semi-settling. Khadka (2010) proposed that the shifting cultivation system in Nepal (Khoriya) has transitioned to a more productive agroforestry farm. Evans, Phanvilay, Fox, \& Vogler (2011) added that shifting cultivation system has been transitioning to a rubber forest in Laos. Furthermore, Adams et al. (2013) revealed that the shifting cultivation system has undergone a transition that led to a reduction in young secondary forest area as well as decrease the heterogeneity of landscapes in Quilombola, Brazil. In line with that, Mangora (2012) said that the period of 4 years of fallow leads to an unsustainable shifting cultivation activity in Tanzania, Africa. Ribeiro Filho, Adams, \& Murrieta (2014) also asserted that in Brazil, the unsustainability of shifting cultivation activity is caused by the changes in social, economic, political, and cultural conditions of the communities.

The implication of this study is to provide a solution model for local residents in the management of shifting cultivation to work according to their local knowledge. This solution is expected to find a compromise among government policies regarding the prohibition on burning forests and land, and does not against local knowledge of burning land by local residents.

The management of shifting and settle cultivation by local communities in Central Kalimantan is still strongly influenced by local wisdom. However, as soon as they run settle cultivation, there is a lot of progress found. Management of agricultural cultivation is more intensive, more productive and sustainable. Land management is also carried out throughout the year by choosing commodities that are potentially economically and business oriented, such as vegetables. The use of technology has developed by using machinery, especially for rice mills. They also use superior seeds from the local government.

\section{CONCLUSION AND SUGGESTION}

The identification of local wisdom in the management system of shifting cultivation of Dayak Ngaju community in Central Kalimantan portrayed in a cultivated culture has the essence of local wisdom. The culture can be understood as; (1) a harmonious relationship with nature as a comprehension that forest and land is a source of life, (2) not the cause of forest and land fires because the managed land is not too extensive (12 ha) supported with firebreaks and short combustion time (3-4 hours), (3) the activities are carried out communally and jointly (gotong royong), and (4) a local knowledge that has good values. However, this system has transitioned from shifting cultivation to intensively settled cultivation system with changing cropping patterns throughout the year.

This study produces findings on the management model of local wisdom-based farming in the communal system, mutual cooperation and mixed farming patterns (rice fields, rubber, fruits, sengon trees, and jelutung). This sustainable agriculture management model has been going on for generations to form a social culture that is still strong and binds on the local population in agricultural life.

\section{ACKNOWLEDGEMENT}

This article is a part of the research of Doctoral Studies at the Graduate Program of Agricultural 
Sciences, Faculty of Agriculture, Universitas Brawijaya. The researchers would like to thank to the community of Mantangai District who helps during the research process, as well as the Ministry of Technology and Higher Education of Indonesia for the support of scholarships. The research also received doctoral grant scheme under the Directorate of Research and Community Service of Directorate General of Research and Development Reinforcement (DRPM Ditjen Penguatan Risbang).

\section{REFERENCES}

Adams, C., Chamlian Munari, L., Van Vliet, N., Sereni Murrieta, R. S., Piperata, B. A., Futemma, C., ... Spressola-Prado, V. L. (2013). Diversifying Incomes and Losing Landscape Complexity in Quilombola Shifting Cultivation Communities of the Atlantic Rainforest (Brazil). Human Ecology, 41(1), 119-137. https://doi.org/10.1007/s10745-012-9529-9

Amare, D., Wondie, M., Mekuria, W., \& Darr, D. (2019). Agroforestry of Smallholder Farmers in Ethiopia: Practices and Benefits. Small-Scale Forestry, 18(1), 39-56. https://doi.orq/10.1007/s11842-018-9405-6

Berkes, F., Folke, C., \& Gadgil, M. (1995). Traditional Ecological Knowledge, Biodiversity, Resilience and Sustainability. In C. A. Perrings, K.-G. Mäler, C. Folke, C. S. Holling, \& B.-O. Jansson (Eds.), Biodiversity Conservation: Problems and Policies (pp. 281-299). Dordrecht: Springer Netherlands. https://doi.org/10.1007/978-94-011-0277-3 15

Bhagawati, K., Bhagawati, G., Das, R., Bhagawati, R., \& Ngachanngachan, S. V. (2015). The Structure of Jhum (Traditional Shifting Cultivation System): Prospect or Threat to Climate. International Letters of Natural Sciences, 46, 16-30. https://doi.org/10.18052/www.scipress.com/ilns .46 .16

Bhushan, S., Singh, P. K., Telidevara, S., \& Kumar, S. (2019). Understanding Livelihood Diversification: A Case Study of Mushroom Farming in Bihar. In A. K. J. R. Nayak (Ed.), Transition Strategies for Sustainable Community Systems: Design and Systems Perspectives (pp. 153-167). Cham: Springer International Publishing. https://doi.org/10.1007/978-3-03000356-2 14

BPS Kalimantan Tengah. (2017). Kalimantan Tengah Province In Figure (Publ: 62560.1711).
BPS-Statistics of Kalimantan Tengah Province.

Burns, H. L. (2015). Transformative Sustainability Pedagogy: Learning From Ecological Systems and Indigenous Wisdom. Journal of Transformative Education, 13(3), 259-276. https://doi.org/10.1177/1541344615584683

Cairns, M., \& Garrity, D. P. (1999). Improving shifting cultivation in Southeast Asia by building on indigenous fallow management strategies. Agroforestry Systems, 47(1), 37-48. https://doi.org/10.1023/A:1006248104991

Das, S., \& Das, M. (2014). Shifting Cultivation in Tripura - A Critical Analysis. Journal of Agriculture and Life Sciences, 1(1), 48-54. Retrieved from http://jalsnet.com/journals/Vol 1 No 1 June 2 014/6.pdf

Evans, T. P., Phanvilay, K., Fox, J., \& Vogler, J. (2011). An agent-based model of agricultural innovation, land-cover change and household inequality: The transition from Swidden cultivation to rubber plantations in Laos PDR. Journal of Land Use Science, 6(2-3), 151-173. https://doi.org/10.1080/1747423X.2011.558602

FAO, IWGIA, \& AIPP. (2015). Shifting Cultivation, Livelihood and Food Security New and Old Challenges for Indigenous Peoples in Asia. In C. Erni (Ed.), Shifting cultivation, livelihood and food security (p. 434). Bangkok: FAO. Retrieved from http://www.fao.org/3/a-i4580e.pdf

Fernández-Ferrín, P., Calvo-Turrientes, A., Bande, B., Artaraz-Miñón, M., \& Galán-Ladero, M. M. (2018). The valuation and purchase of food products that combine local, regional and traditional features: The influence of consumer ethnocentrism. Food Quality and Preference, 64, 138-147. https://doi.org/10.1016/j.foodqual.2017.09.015

Kansanga, M., Andersen, P., Kpienbaareh, D., Mason-Renton, S., Atuoye, K., Sano, Y., ... Luginaah, I. (2019). Traditional agriculture in transition: examining the impacts of agricultural modernization on smallholder farming in Ghana under the new Green Revolution. International Journal of Sustainable Development \& World Ecology, 26(1), 11-24. https://doi.org/10.1080/13504509.2018.149142 $\underline{9}$

Khadka, R. (2010). Transition from slash-and-burn (Khoriya) farming to permanent agroforestry in the middle hills of Nepal; An analysis of costs, benefits and farmers' adoption. Norwegian University of Life Sciences, Department of 
International Environment and Development Studies Retrieved from https://core.ac.uk/download/pdf/52080290.pdf

Kurniawan, A., Hartoyo, S., \& Syaukat, Y. (2011). Analisis efesiensi ekonomi dan daya saing jagung pada lahan kering di Kabupaten Tanah Laut, Kalimantan Selatan. Jurnal Agribisnis Perdesaan, 01(02), 83-99. Retrieved from http://repository.ipb.ac.id/handle/123456789/4 $\underline{5306}$

Lumangkun, A., \& Wardenaar, E. (2017). Kearifan Lokal Masyarakat Dalam Kegiatan Ladang Berpindah Di Dusun Laek Desa Bengkilu Kecamatan Tujuh Belas Kabupaten Bengkayang. Jurnal Hutan Lestari, 5(4), 10271034. Retrieved from http://jurnal.untan.ac.id/index.php/imfkh/article view/23017/0

Mangora, M. M. (2012). Shifting Cultivation, Wood Use and Deforestation Attributes of Tobacco Farming in Urambo District, Tanzania. Current Research Journal of Social Sciences, 4(2), 135$140 . \quad$ Retrieved from http://maxwellsci.com/print/crjss/v4-135140.pdf

Mokpokpo, A.-K. (2016). The Use of Sculptures to Augment Naming of Buildings in Honor of Heroes and Heroines in Ho Polytechnic, Ho, Ghana. Asian Journal of Education and Training, 2(2), 34-38. https://doi.org/10.20448/journal.522/2016.2.2/ $\underline{522.2 .34 .38}$

Patel, T., Karmakar, S., Sanjog, J., Surendra, K., \& Chowdhury, A. (2013). Socio-economic and environmental changes with transition from shifting to settled cultivation in North-Eastern India: an ergonomics perspective. International Journal of Agricultural Science and Research (IJASR), 3(2), 117-135.

Rahman, S. A., Rahman, M. F., \& Sunderland, T. (2012). Causes and consequences of shifting cultivation and its alternative in the hill tracts of eastern Bangladesh. Agroforestry Systems, $84(2)$,

\section{https://doi.org/10.1007/s10457-011-9422-3}

Ribeiro Filho, A. A., Adams, C., \& Murrieta, R. S. S. (2014). The impacts of shifting cultivation on tropical forest soil: a review. Boletim Do Museu Paraense Emílio Goeldi. Ciências Humanas, 8(3), 693-727. https://doi.org/10.1590/s1981$\underline{81222013000300013}$

Rodríguez, I., Sletto, B., Bilbao, B., Sánchez-Rose, I., \& Leal, A. (2018). Speaking of Fire: Reflexive Governance in Landscapes of Social Change and Shifting Local Identities§. Journal of Environmental Policy and Planning, 20(6), 693712.

https://doi.org/10.1080/1523908X.2013.766579

Singh, S., Purohit, J. K., \& Bhaduri, A. (2016). Shifting Cultivation in Odisha and Chhattisgarh: Rich agro-biodiverse systems under risk. Jharkhand Journal of Development and Management Studies XISS, 14(2), 7023-7036.

Temudo, M. P., Figueira, R., \& Abrantes, M. (2015). Landscapes of bio-cultural diversity: shifting cultivation in Guinea-Bissau, West Africa. Agroforestry Systems, 89(1), 175-191. https://doi.org/10.1007/s10457-014-9752-z

Utina, R. (2017). Ecological Intelligence of Coastal Community on Biodiversity Conservation (Case Study of Bajau Coastal Communities, Gorontalo). _Journal of Biological Sciences, 4(1), $\quad$ 54-57. https://doi.org/https://doi.org/10.24843/metam orfosa.2017.v04.i01.p09

van Vliet, N., Adams, C., Vieira, I. C. G., \& Mertz, O. (2013). "Slash and Burn" and "Shifting" Cultivation Systems in Forest Agriculture Frontiers from the Brazilian Amazon. Society and Natural Resources, 26(12), 1454-1467. https://doi.org/10.1080/08941920.2013.820813

Wida, E., Irianto, H., \& Anam, C. (2015). Study of Staple Food Identification By Local Wisdom Base on Pre-Prosperous Household in Central Java. Agriekonomika, 4(1), 66-79. https://doi.org/http://dx.doi.org/10.21107/agrie konomika.v4i1.675.g595 